\title{
Steve Murphy, Trois manuscrits autographes de Rimbaud
}

\section{Ida Merello}

\section{(2) OpenEdition}

1 Journals

\section{Edizione digitale}

URL: http://journals.openedition.org/studifrancesi/33493

DOI: 10.4000/studifrancesi.33493

ISSN: 2421-5856

\section{Editore}

Rosenberg \& Sellier

\section{Edizione cartacea}

Data di pubblicazione: 1 décembre 2005

Paginazione: 667-668

ISSN: 0039-2944

\section{Notizia bibliografica digitale}

Ida Merello, «Steve Murphy, Trois manuscrits autographes de Rimbaud», Studi Francesi [Online], 147 (XLX | III) | 2005, online dal 30 novembre 2015, consultato il 19 avril 2021. URL: http://

journals.openedition.org/studifrancesi/33493 ; DOI: https://doi.org/10.4000/studifrancesi.33493

Questo documento è stato generato automaticamente il 19 avril 2021.

\section{(c) (i) (9)}

Studi Francesi è distribuita con Licenza Creative Commons Attribuzione - Non commerciale - Non opere derivate 4.0 Internazionale. 


\title{
Steve Murphy, Trois manuscrits autographes de Rimbaud
}

\author{
Ida Merello
}

\section{NOTIZIA}

STEVE MURPHY, Trois manuscrits autographes de Rimbaud, «Histoires littéraires» $\mathrm{n}^{\circ} 17$, janv.-mars 2004, pp. 35-58.

1 Il catalogo dell'esposizione di Livres du cabinet de Pierre Berès, edito da Emmanuelle Toulet, fornisce tre dei quattordici manoscritti sconosciuti (Patience, Soir historique e Génie), cui Murphy aggiunge due documenti: il retro del foglietto su cui Rimbaud ha ricopiato Patience e un complemento allografo significativo per la storia delle Illuminations, di dubbia attribuzione. L'A. si interroga sui testi, controllando le varie lezioni e interpretazioni, per arrivare alla conclusione che $\mathrm{i}$ dati sono talmente complessi da rendere inevitabile l'approfondimento degli studi, anche se, per quanto riguarda le Illuminations, saranno le deduzioni a partire dai documenti ormai accessibili che faranno avanzare la comprensione della raccolta. 